Herman Lombaerts

Catholic University of Leuven, Belgium

\title{
The Impact of the Status of Religion in Contemporary Society upon Interreligious Learning
}

\section{Abstract}

The author analyses the growing importance of IRL against the background of a changing European society. Based on sociological research, the traditional status of the Christian religion - and the monoreligious education that normally accompanies it - is seriously being challenged by the process of secularisation and the growing plurality or religious attitudes and beliefs among people in the West. Europe has become a complex network of influences that constitute the actual symbolic field employed by people in their search for truth. The interest for religion is still very much alive. People are not endlessly indifferent but still hope to find (religious) truth and meaning, even if this process has become much more complex today. In this context, interreligious dialogue itself becomes a religious act. The status given by a religion to other religions is of crucial importance for its ultimate credibility. In this line of thought, religious education should transcend both a purely monoreligious approach and a purely objective-comparative (multireligious) approach, and instead should cultivate in the pupils - at the very borderlands of the different religious, cultural and geo-political territories - an attitude of practising interreligious dialogue as a religious event.

\section{Keywords}

Status of religion, laïcité-secularity, religious indifference, interreligious dialogue, interreligious learning. 


\section{Introduction}

According to surveys and concrete experiences at the grass-roots level, monoreligious education is being placed under pressure by the growing secularisation and plurality of Western Europe. Due to the growing diversification of identities among the faithful, even within the same tradition, the religious field itself becomes complex and obscure. Reminding one of Rahner's description of the major phases of the church's history, Waldenfels comments upon the emergence of a polycentric world church in the second half of the twentieth century. As a result, the churches reconsider the role that they can play in contemporary society in interaction with other religions and new religious movements ${ }^{1}$.

The difference with the prevalence of a worldwide missionary proclamation of the Christian faith, and of the exclusive interpretation of the universal salvation of all people in Christ is obvious. The Christian Tradition being the norm, other religions were always evaluated from within that tradition. The hope for unity with other religions was formulated from the Christian perspective. Today, however, given the outspoken worldwide communication, the multiplicity of religious creeds and models of religious behaviour heightens the need for appropriate criteria and critical discernment of the truth-value, function, legitimisation, meaning, and relevance of religions. During the past two centuries, the religious traditions and their social position in society have been severely criticised ${ }^{2}$. Of course, the critique of religion, or Religionskritik, in an intra-ecclesial or extra-ecclesial perspective, directly or indirectly parallels the changes religious traditions experience as the result of their confrontation with other traditions ${ }^{3}$. But the widespread sceptical attitude of modern thinking in the Western world, Europe in particular, and the rational examination of religious behaviour by the human sciences have a deep impact upon the perception of religion by the public, and upon the way religions present themselves.

It is particularly this change in self-presentation and perception that needs to be looked at when launching IRL (Interreligious Learning) as a core paradigm

${ }^{1}$ H. Waldenfels, Wandlungen in der Beurteilung und Kritik nichtchristlicher Religionen durch das Christentum aus katholischer Sicht, in: H.R. Schlette (ed.), Religionskritik in interkultureller und interreligiöser Sicht, Bonn 1998, Borengässer, p. 27-34.

2 J.A. van der Ven, Kontingenz und Religion in einer säkularisierten und multikulturellen Gesellschaft, in: H.-G. Ziebertz, J. A.van der Ven (eds), Religiöser Pluralismus und interreligiöses Lernen, Kampen 1994, Kok Pharos, p. 15-37.

${ }^{3}$ H. R. Schlette, Einleitung, in: H.R. Schlette (ed.), Religionskritik in interkultureller und interreligiöser Sicht, op. cit., p. 2-4; L. Nagle, Religion nach der Religionskritik, Wien 2003, Akademie Verlag. 
for religious education. According to this assumption, one may put the focus upon 'dialogue', conversation, communication, learning, or upon the changing relationship between the different religious traditions. Religions, however do not exist in a vacuum. They are constituted by the context in which they emerged or were introduced. What religions concretely represent in these contexts and what religions say about themselves are the results of the outcome of an interaction with their environment. As the terms and content of these interactions are changing, what religion stands for is also a changing reality ${ }^{4}$. For van der Ven, religion itself is a contingent reality 5 . The plurality of Christian beliefs and world religions stresses the contingent dimension despite the universal meaning attributed to Gods salvation. Hence the question: what is the social standing, or status, of religions in a particular situation? ${ }^{6}$ And what are its implications for interreligious learning?

Besides the many questions to be raised about what IRL stands for in principle, as spelled out in the introductory of this book, the transition from mono-religious education to IRL is not evident from an institutional, educational, or legal point of view. As the questions suggest, nearly all the aspects of the institutional setting of RE are affected and need to be reconsidered. The different components of the possible specific domain of IRL largely depend upon contextual and shifting circumstances. The distinct actors committed to IRL or those involved in its implementation echo different interests and represent a mixture of institutional and educational responsibilities. In fact, IRL suggests that, given the circumstances of religious plurality, teachers now have to work with an open situation whereby the subjects themselves, in the context of a formal curriculum, play an important role in the choice of the content to be explored.

\section{Interreligious Learning in its Systemic Context}

The recent emergence of the outspoken and officially recognised interest for ecumenism and open relationships with non-Christian religions is inherently related to the changes of Western European society. Hence, to consider religions in their social context is important for seeing more clearly the impact of the social

${ }^{4}$ J.A. Beckford, Th. Luckmann (eds.), The Changing Face of Religion, London 1989, Sage, p. 1; G. Ward, Cultural transformation and Religious Practice, Cambridge 2005, Cambridge University Press, p. 62ff.

${ }^{5}$ J.A. van der Ven, Kontingenz und Religion, op. cit., p. 27-32.

${ }^{6}$ H. Lombaerts, D. Pollefeyt (eds.), Hermeneutics and Religious Education, Leuven 2004, Peeters, p. 12-15. 
standing of religions upon IRL. The following four different perspectives will be taken into consideration:

- the historical perspective

- the geo-political perspective

- the rational interpretation of religious beliefs and behaviour

- the theological debates and interreligious dialogue.

\section{Historical Perspective}

Modernity is generally seen as the dynamic force of fundamental changes in Western European society. Primarily, Modernity detached freedom from a specific context and from religious traditions. Freedom then claims autonomy, sets its own unconditional and definitive laws, controls all of the institutions, and constitutes the basis of the self-assured human being. The pre-modern certainties and frames of reference collapsed and lost their credibility. A withered tradition is not granted authority in modern society.

Although being one of the main instigators of the emancipation process proper to modernity, the Christian churches experienced fundamental difficulties in dealing with the outcome of Modernity. For example, the so-called secularisation and theological proposal to recognise the correlation between human reality and the Christian faith still meet with a lot of resistance in the pastoral and doctrinal field. Although defending the individual person and religious freedom, too often over the past centuries the churches went along with modernity in opposing its main options or in entrenching itself in intra-ecclesial matters, and, as a consequence, began losing its grip upon society. But, when the churches are opposing each other as modern society sometimes claims and when religions are no longer relevant in public life, do they still have an autonomous, independent core, which has the authority to challenge the political or cultural assumptions propagated in an open society? ${ }^{7}$.

The importance of the conflicts related to attributing an absolute priority to freedom in modern society is clearly discernable in two processes that are at the centre of multiple debates today: who has what kind of authority over religion in society? (the laïcité-debate), and do Europeans tend to eradicate religions root and branch, as some seem to argue? (the issue of religious indifference). The remarkable changes of the concept of laïcité over the past decades and the changing interest for religion are two influential factors for IRL.

\footnotetext{
${ }^{7}$ W. Kasper, L'Eglise et les processus modernes de la liberté, "Istina” 49 (2004), p. 115-123.
} 


\section{The Lad'cité-Secularity Debate}

Many a representation of the French Revolution and of the separation between Church and State associates laïcité with a negative, anti-clerical, anti-religion political strategy. Philipp Portier calls it the "laïcité primitive" . Historically speaking, in Europe, laïcite is to be situated at the heart of the development of Christianity 9 . In the $16^{\text {th }}-17^{\text {th }}$ centuries, the secular, civil authority instituted itself in order to achieve a juridical policy of pacification among Catholics and Protestants ${ }^{10}$. By recognising that the political unity was unreachable without religious peace, a new perspective emerged in the name of civil coherence. A new lay mindset went along with a new religious mindset; both ways of approaching the social reality were interdependent and necessary to keep the systems in harmony. The close interconnectedness between a Catholic absolutist monarchy and the Church in the Ancien Régime had become a major abuse and was placing the whole of society at risk. In the relationship of the new society and issue of freedom, people faced new questions: what does it mean to live according to one's personal convictions, be they secular or religious convictions, in a political system which claims its own authority, independently of what each individual believes? At once, a 'secular philosophy' called the tradition, a well established 'Catholic, or Christian philosophy', to clarify its main theological assumptions in response to the alternative, mere secular model of construction of a new social reality ${ }^{11}$.

Laïcité was then the result of political wisdom, a subtle sense of balance, which does not force anybody to give up personal convictions, but rather introduces a new art of living together ${ }^{12}$. Laïcité represents a double memory: the history of a legal process of putting things into a new civic order, and the history of a social process of secularisation. Institutions are separated and secularised, but the religious cults are respected as regards to their proper and specific aims. Or, as Charles De Gaulle put it: the State is secular, but France is Christian.

${ }^{8} \mathrm{Ph}$. Portier, De la séparation à la reconnaissance. L'évolution du régime Français de laïcité, in: J.-P. Willaime, J.-R. Armogathe (eds.), Les mutations contemporaines du religieux, Turnhout 2003, Brepols, p. 5.

${ }^{9}$ B. Dupuy, La laïcité, principe de respect d'autrui et d'unicité nationale, "Istina" 49 (2004), p. $160-177$.

${ }^{10}$ Cf. e.g., the Treaty of Westphalia (1648), the "religious peace" of Augsburg (1555), "the Edict of Nantes" (1598).

${ }^{11}$ E. Poulat, Notre laïcité publique: La France est une République lä̈que (Constitutions de 1946 et 1958), Paris 2003, Berg International, p. 295-302.

${ }^{12}$ Ibid., p. 13. 
The harsh confrontation initiated by the French Revolution at the end of the $18^{\text {th }}$ century between the new civil consciousness and absolutist aspirations for freedom, equality, fraternity, and the monopoly position of Christianity, the Catholic church in particular would take two centuries to establish a new peaceful order. Relying upon E. Poulat's research, Philippe Portier distinguishes three main phases in the gradual "mutation" of the French laïcité, and recognises how in the wider European context different clusters of countries adopted similar policies in their dealings with the relationship between Church and State.

$1 /$ The original principle of laïcité reached its most explicit form in the secularisation law of 1905: the total separation from the religious institution ${ }^{13}$. Freedom of conscience, privatisation of religious belonging, and the transcendence of the political domain were the most striking priorities.

2/ A new situation occurred with the plentiful reactions against the supremacy of the State (second half of the $20^{\text {th }}$ century) ${ }^{14}$. The State was accused of exaggerated interferences with private matters of e.g. the Churches. In order to meet the protests and claims, the State organised policy committees, forums, and arenas. These were intended to take into account the sensitivities and aspirations of the different sections of a rapidly changing society. The State presented itself as co-operating with the law and was willing to subsidise all kinds of social projects, including the ones organised by the different religions. But, more importantly, the public space was constituted on the basis of the recognition of private identities ${ }^{15}$. The claim of second generation-migrants to enjoy 'equality' and republican citizenship (ethnicisation process) forced the State to integrate religious and cultural 'differences', beyond the original Jewish, protestant and catholic establishment. The principles of freedom, autonomy and self-realisation were extended in an unexpected and unforeseen way. Particular cultural and religious identities, including the Jewish-Christian tradition, were no longer seen as a danger or an obstacle to the common good of society. Historically, the original militant anti-religious or anti-clerical connotation of laïcité had been abandoned. In addition, the European Union, as a juridical entity is introducing a positive concept of freedom of religious belief, and is willing to recognise the public character of religious traditions ${ }^{16}$. Because there is no history, tradition or juridical rule set for these matters, the European Union is in fact a laboratory,

\footnotetext{
${ }^{13} \mathrm{Ph}$. Portier, De la séparation à la reconnaissance, op. cit., p. 5-6.

${ }^{14}$ Ibid., p. $10 \mathrm{ff}$.

${ }^{15}$ Cf. also C. Taylor, K.A. Appiah, J. Habermas, A. Gutmann, Multiculturalis. Examining the
} Politics of Recognition, Princeton 1994, Princeton University Press, p. 25-73.

${ }^{16} \mathrm{Ph}$. Portier, De la séparation à la reconnaissance, op. cit., p. 14. 
not only for granting a public space to a growing plurality of religions and religious movements, but for integrating the different legal systems and models of harmonising the interaction between State and Churches / religions. Indeed, besides the French experience with the process of secularisation (laïcité), other countries have a long-standing tradition of dealing with the same issue. Finland, Denmark, Greece and Great-Britain selected one denomination as the "national", "dominant" or "State" religion, whereby a mutual penetration guaranteed harmony. Germany, Belgium, Italy and Spain adopted a flexible separation between Church and State. Also, the traditional European churches adopted the democratic mindset more explicitly within their belief systems and ecclesial government. All European countries are confronted with the impact of non-catholic or non-Christian religions, religious minorities, and new religious movements. The French society cannot stop or ignore the impact of the European context. However, as J.-P. Willaime commented, the new face of a pluri-religious Europe has not been shaped yet ${ }^{17}$.

3 / But the real 'reform' or fundamental mutation became obvious during the past decade, partly as the result of (ethical) initiatives of Christian churches in the public domain. The French State is now welcoming religions within the public realm; looking for synergy, rather than exclusion, for a harmony between unity and plurality, equality and alterity, the public and the private ${ }^{18}$. We now recognise a benevolent and sympathetic kind of laïcité. The State is willing to take far reaching financial responsibilities for schools, cultural institutions, public buildings, irrespective of their religious or ideological background. The school, for example is perceived as a space for life and immanence, open to religious and cultural differences, enabling the free speech of students, permitting absenteeism for religious reasons and setting the rules for externalised religious symbols. The State opts for a laïcité d'intelligence, an open, cooperative, understanding kind of secular mindset. Thus, religions now are granted by the State to participate in a new way in the public life. The representatives are invited to cooperate for special missions or to participate in the ethical/political discernment of crucial issues or dilemmas.

The transition of the status of religion in society, in France, is a remarkable historical adventure ${ }^{19}$. The civil authorities attributed a new juridical and social position to the churches. It took the churches a long time to change

${ }^{17}$ J.-P. Willaime, Conclusion, in: J.-P. Willaime \& J.-R.Armogathe, Les mutations contemporaines du religieux, op. cit., p. 128.

${ }^{18} \mathrm{Ph}$. Portier, De la séparation à la reconnaissance, op. cit., p. $17 \mathrm{ff}$.

${ }^{19}$ E. Poulat, Notre laïcité publique, op. cit., p. 373-381. 
the representation they had of their role in society. But, helped by the new Constitutions, they gradually saw the new social and public space given to them, and to grant themselves specific and relevant responsibilities in that new context. From a unitary concept of truth and the absolutist, centralised authority attributed to 'God's will', the churches had to integrate the concepts of 'religious freedom', 'freedom of individual conscience', and 'freedom of cultic celebrations'. They gradually came to understand and appreciate the public status of 'cultural association', as a juridical guarantee for having a social identity, and for organising specific activities. The recognition of personal freedom allowed diversity to be recognised on constitutional and juridical grounds. From hierarchical dependency, people were introduced into the logic of the 'social contract'. The French type of laïcité introduced a generalised system of public freedom for all.

Of course, the mutation of the laïcité reflects the mutation of democracy. A democracy of subsidiary and delegation represents the polyphony of subjective identities, which, for Philippe Portier, raises the question whether such an open society will be able to function well without universalistic ambitions ${ }^{20}$.

In summary, Jean-Paul Willaime recognises four major traits in the mutations of the relationship between society (Modernity), Church, and State ${ }^{21} .1 /$ the mutation of the religious field, related to the mutation of the political domain, results in a new understanding of laïcité, in terms of partnership between Church and State; the States now appreciate the role of churches and religions in a new way; $2 /$ the religious traditions change and transform themselves through their interactions with modernity; mutations are happening within the religious traditions; 3 / the impact of the mondialisation and globalisation processes upon the religious domain should not be underestimated; 4/ growing individualisation is an undeniable trait of religious people in our ultra-modern society.

As a major consequence of these processes, the church now has a more outspoken symbolic status in European civil society. Being part of the postChristian era, the churches have to situate themselves in a different way. Because of their specific ecclesial convictions, the symbolic space offers them opportunities for challenging the social, cultural, and political reality, for reflecting and acting in the name of a less ambiguous institutional position in society. As E. Poulat asserts, to change the public status of religion is, of course, the result of a juridical reform, but it inseparably reflects a cultural

${ }^{20} \mathrm{Ph}$. Portier, De la séparation, op. cit., p. 24.

${ }^{21}$ J.-P. Willaime, Conclusion, in: J.-P. Willaime \& J.-R.Armogathe, Les mutations contemporaines du religieux, op. cit., p. 125. 
revolution as well, with implications for all institutions in society ${ }^{22}$. Obviously, such a fundamental reversal, with its most recent further developments, has far reaching implications for religious education in the Christian communities, as well as in (public) schools.

\section{The "Religious Indifference" Symptom ${ }^{23}$}

According to the Pontifical Council for Culture (Plenary assembly, Rome, March 11-13, 2004), "religious indifference and a growing 'religion of the self' pose a greater challenge to the church than atheism and its denial of the existence of God". The arguments for this kind of diagnosis are inspired by the findings of a world-wide survey. Today, more people than twenty years ago admit that they do not belong to any particular religion, and more people stopped practicing. This would be more the case among young adults than among senior men and women ${ }^{24}$. As cardinal Poupard, the president of the Pontifical Council observed, the "militant and organized atheism" of the Communist era has been replaced by "practical indifference, the loss of interest in the question of God, and the abandonment of religious practices - especially in the Western world" 25 . The cardinal remarked: "The era most menacing to man is not the one that denies the truth, but the one that is not concerned about truth ${ }^{26}$.

In 1983, Mgr Poupard, then Pro-President of the Secretariat for the NonBelievers, presented an interdisciplinary study about 'religious indifference"27. In the Foreword, he underscored the importance of studying the issue from different angles ${ }^{28}$. Indeed, 'indifference' used to be a key word in Christian spirituality, a basic condition for being committed to Gods will. In that sense,

${ }^{22}$ E. Poulat, Notre laïcité publique (n. 12), p. 22.

${ }^{23}$ H. Lombaerts, Różnorodność czy obojętność? Indyferentyzm religijny jako symptom przemian (The difference/indifference dilemma. "Religious Indifference" re-examined as symptom of a mutation), "Katecheta" 48 (2004) Nr 7, p. 4-16.

${ }^{24}$ Survey on 'non belief and religious indifference' carried out by Pontifical Council for Culture in preparation for annual Plenary Assembly, http://www.vatican.va/roman_curia/pontifical councils/cultr/documents/rc_pc_cultr_doc_20040313_where-is-your-god_en.htm; (19.03.2011).

${ }^{25}$ Ibid.

${ }^{26}$ Ibid.

${ }^{27}$ Secrétariat pour les non-croyants, L'indifférence religieuse, Paris 1983 (Rome 1978, Italian text). In 1983 the International Review of Theology, "Concilium" also published an issue on 'religious indifference'.

${ }^{28}$ Ibid., p. 5-6. 
it had a positive connotation. The Reformation, the Enlightenment, and the development of modern, secularised society, on the contrary, initiated attitudes against the established religious traditions, institutions, doctrines, and religious practices. Various authors of this study elucidate the links between the evolution of civil society (e.g. secularisation, urbanisation, industrialisation, emigration) and religious indifferentism. Religious indifference is then diagnosed as having a negative, destructive impact upon people as regards to their religious attitudes and affiliations ${ }^{29}$.

For Gaudium et Spes, atheism ${ }^{30}$ was still considered as the main challenge for the church. The main reason for atheism being that those not following the dictates of their conscience shut out God and try to dodge religious questions. "The remedy which must be applied to atheism, however, is to be sought in a proper presentation of the Church's teaching as well as in the integral life of the Church and her members" ${ }^{\prime 31}$. In the Constitution, 'religious indifference' was not even mentioned ${ }^{32}$.

In its negative sense the complaints about religious indifference have been formulated since the seventeenth century, and it was a main issue of concern throughout the eighteenth, the nineteenth, and well into the twentieth centuries ${ }^{33}$. Preachers, for example, blamed people who came to listen to the Word of God without interest; they were accused of being 'indifferent'. In their writings Pascal

${ }^{29}$ Cf. the contributions of G. Cottier, L. Mozart, G. De Rosa in "Concilium” 1983.

${ }^{30} \mathrm{In} \mathrm{n}^{\circ} 19$, the Constitution lists a variety of responses people may experience in relationship to God and to religion, mainly associated with the word 'atheism': denial, agnosticism, meaninglessness of God and religion, relativism, misinformation, engrossment in earthly affairs. "Modern atheism... stretches the desires for human independence to such a point that it poses difficulties against any kind of dependence on God." On the other hand, it "anticipates the liberation of man especially through his economic and social emancipation. "Some never get to the point of raising questions about God, since they seem to experience no religious stirrings nor do they see why they should trouble themselves about religion".

${ }^{31}$ Ibid., $\mathrm{n}^{\circ}$ 21; Cf. also bishop Grab (Chur), President of the Council of European Bishops Conferences, on the occasion of the pilgrimage of European bishops to Santiago de Compostella (2004): despite its own weaknesses and failures, the Roman Catholic Church has to address the moral decadence and religious indifference, which seems to control Europe at the moment, with a powerful proclamation.

${ }^{32} \mathrm{~B}$. Mondin associates the descriptive approach to atheism, in: Gaudium et Spes, with religious indifference. He then continues: "religious indifference is perhaps-many people are inclined to think so today-the most widespread and, from some standpoints, the most serious form of unbelief", "L’Osservatore Romano", Weekly Edition in English, 27 July 1978, p. 9.

${ }^{33}$ E. Poulat, Quand nous parlons d'indifférence..., "Catéchèse" (1984), Juillet, p. 9-17. 
$(1623-1662)^{34}$ and Bossuet (1627-1704) $)^{35}$ reacted vehemently against atheists, deists, free thinkers, 'Libertins ${ }^{36}$, Quietists ${ }^{37}$, a worldly attitude separated from religion, or against tolerance towards Protestantism.

The famous essay of the French priest, F.R. de La Mennais, had a deep impact because his book (two volumes) marked a passage from indifference to religion (seventeenth century) to indifference between religions (nineteenth century) ${ }^{38}$. According to La Mennais, it is not that easy to be 'indifferent' in religious matters. Indifference, understood as a permanent attitude of the soul is contradictory to the human nature, and destroys the human person in essence ${ }^{39}$. He identifies three systems of indifference, the first one of which states that all religions are indifferent; religion is a political organisation, necessary for the people only ${ }^{40}$. Religious indifference was thus perceived as a mental system, an argued way of thinking with universal aspirations, and was identified as 'indifferentism'. Religious indifferentism was condemned as an error, heresy and $\sin ^{41}$.

When today a growing number of people admit not to belong to a particular religion, they do not necessarily lack interest in religions or life visions. "Religious indifference" is too massive a diagnosis, which is contradicted by

${ }^{34}$ B. Pascal, L. Lafuma, Pensées, Paris 1978, Seuil, p. 427-429, p. 181-191; D. Wetsel, Pascal and Disbelief. Catechism and Conversion in the Pensées, Washington 1994, Catholic University of America Press, p. 49-129, $327 \mathrm{ff}$.

${ }^{35}$ J.-B. Bossuet, Oeuvres complètes, textes établis et annotés par l'abbé Velat - Y. Champailler, Paris 1961, Gallimard; Cf. also G. Cottier, Les fondements de l'indifférence en philosophie de la religion, in L'indifférence religieuse, Le Point Théologique 41, p. 44ff.

36 'Libertins' (seventeenth century) were originally dissidents of protestant sects in the North of France; later it was also associated with a literary movement. The Libertins are identified with an irreligious mindset, refusing revelation, adopting free interpretation of Scriptures, negating sin.

${ }^{37}$ Quietism (Miguel de Molina, $17^{\text {th }}$ century) states that perfection is achieved in full passivity; the soul rests in Gods presence. Ascetic practices are superfluous. Quietism is related to every mystical orientation, which minimises the human activity. Quietism was condemned by Innocentius XI in 1687.

${ }^{38}$ F. R. de Lamennais, Essai sur l'indifférence en matière de religion, Ducasse, Paris 1834, 2 v. Cf. also C. Marechal, La Mennais, la dispute de l'Essai sur l'indifférence d'après des documents nouveaux et inédits, Paris 1925, Champion.

${ }^{39}$ D. E. Lamennais, Essai sur l'indifférence en matière de religion, op. cit., p. 37.

${ }^{40}$ Ibid., Vol. 1, pp. 53ff. Cf. also C. Marechal, La Mennais, op. cit., p. $2 \mathrm{ff}$.

41 "Indifferentism equalizes all religions, and gives equal rights to truth and error." (Cardinal Manning); indifferentism is "a heresy consisting in an unconcern for any particular creed, provided the morals be right and good" (Gregory XVI). See M. Vos, Encyclical On liberalism and religious indifferentism of Pope Gregory XVI - August 15, 1832; Cf. also the Encyclical Pascendi Domini Gregis by Pius X, 1907; Cf. also D. Concina (O.P.) - C. E. Re della Sardegna, Della religione rivelata contra gli ateisti, deisti, materialisti, indifferentisti, che negano la verita de misteri, libri cinque, Venezia 1754, presso Simone Occhi, p. 2-3, $281 \mathrm{ff}$. 
the careful study of the results of surveys of the past forty years. The so-called 'religious indifference' diagnosis reveals a misunderstanding. The unitary truth and centralised authority in the Catholic church are perceived as the exclusive category for evaluating and diagnosing people's religiosity, based upon a linear understanding of the link between proclamation / teaching of the Church's doctrine, and the obedient response of the faithful through liturgy, moral and doctrinal observance. In reality, the 'reception' of what is offered by the pastoral ministers leads to the construction of a personal faith response, for which the believer is responsible, and thus by itself ends up in an unforeseeable diversity among the faithful. When the responses differ from the standardised and expected behaviour, it does not mean that people reject religiosity as such, or stop being related to a particular faith tradition. Rather, 'religious indifference' is a symptom of a shift occurring in the religious consciousness of people in Western Europe and as noticed already, among certain groups of people in other continents. Sociologists and philosophers claim that, while it is an evolution proper to modern society, modernity itself is the result of the influence of Christianity upon Western society (Weber, e.g.). And thus, the present shift in religious attitudes, or 'de-christianisation', is another phase in the historical evolution of religions in the context of a globalised and complex modern society. Despite the highly diversified attitudes of Europeans as regards to their religious traditions, surveys point out that the interest for religion and the search for truth is still alive and well.

\section{The Geo-Political Perspective}

According to Poupard's survey, in the United States, atheism and non-belief are not increasing but there is a widespread dropping out of specific religious confessions. In Africa, Asia, and Latin America many people are still animated by popular religious piety at the heart of their respective cultures, says the report. In Africa and Latin America, more than non-belief, the main concern is a boom in sects and very active cults. China is still under the power of atheism like Vietnam, North Korea and Cuba. In Asia the problem is not the absence of religion but a superimposition and complex coexistence of many different religions ${ }^{42}$. According to Cardinal Poupard, in Europe, there is a clear decline in membership of major Churches and in followers of major systems, while there

$42 \mathrm{http} / / / \mathrm{www} . v a t i c a n . v a /$ roman_curia/pontifical_councils/cultr/documents/rc_pc_cultr_doc 20040313_where-is-your-god_en.htm (19.03.2011). 
is renewed interest for religion in itself, with a swarm of new forms of pagan religiosity. The striking element in the description is the supposed link between geographical regions and political systems on the one hand, and the responses of its populations to Christianity and to other traditions or religious movements, on the other hand. A closer look at the European situation, for example may confirm that religion is not in the first place a matter of personal belief, but of belonging to a particular geo-political territory.

No doubt, religions played a decisive role in the construction of States and nations, of national, regional, social, and cultural identities. The territory conditions the religious belonging. Ireland, Poland, Lithuania, Belgium, Italy, Spain, Croatia, ex-Yugoslavia, are predominantly Catholic, Scotland is Presbyterian, England Anglican, Serbia, Greece and Russia are orthodox, Sweden, Denmark, Latvia are Lutheran, Germany, Switzerland, Hungary, and Czech Republic are Catholic/ Protestant, Norway and Estonia agnostic, etc. Historically speaking, politics and religion were closely associated in the formation of the European continent. This situation suggests that, once a territory is linked to a particular religion, it is taken for granted that it will never change, because this link guarantees political, social and religious stability.

According to the European Values Studies and worldwide surveys, at first glance, the geo-political maps of world religions are still valid. However, important shifts are to be studied for understanding how people today perceive and receive religion. In many regards, religious and spiritual boundaries no longer coincide with their traditional territories. The arrangement and complement of the world's nations has altered during the twentieth century, due primarily to the demise of empires, culminating in the collapse of the Soviet Union. This process has affected religion profoundly. Ethnic and religious mixing has increased around the world ${ }^{43}$. Although loyalties remain between traditional religions and nationalism, a political unity is no longer linked with religious homogeneity (which means the end of cujus regio, ejus religio). Admittedly, still $75 \%$ (of the population of 452 million in the European Union of the 25 members) identifies itself as Christian (in comparison to $85 \%$ in 1981): $55 \%$ Catholics (impact of Polish membership), $15 \%$ Protestants (29\% in 1981), 5\% Anglicans, 3\% Orthodox Christians, besides 2,5\% Muslims, $0,5 \%$ Jews, and $19 \%$ (other sources: $25 \%$ ) who identify themselves 'without religion' (13\% in 1981)

\footnotetext{
${ }^{43}$ N. Smart, Atlas of the World's Religions, Oxford 1999, Oxford University Press, p. 12-13.

${ }^{44}$ J.-P. Willaime, Europe et religions. Les enjeux du XXIe siècle, Paris 2004, Fayard, p. 52-62.
} 
The situation differs considerably from country to country, as illustrated eloquently by the European Value Studies ${ }^{45}$. The evolution observed over the past decades reveals underlying fundamental shifts in the perception and reception of religious traditions. In 1999-2000, 77,4\% of Europeans believe in God: Portugal 94,4\%, Ireland 95\%, Greece 93,8 \%, France61,5\%, Sweden 53,4\%, Holland $61,1 \%$. When the age factor is taken into consideration, the change becomes obvious. In Western Europe, in 1998, 85\% of the 60-plus age group believe in God, in comparison to $68 \%$ of the $18-24$ group (30\% in Holland, $47 \%$ in France). Other sources mention $72 \%$ of the British as 'without religion', $58 \%$ of the French, and $21 \%$ of the Dutch population. When comparing the professed religious identity with religious practice, the situation is even more diversified. In France, 61,5\% of the population professes adherence to the Catholic Church, but only 7,6\% practices $(60,4 \%$ never go to any religious service). The religious practice rate is $56,9 \%$ in Ireland, $40,6 \%$ in Italy, $25,5 \%$ in Spain, $14,4 \%$ in Britain, $13,6 \%$ in Germany, 2,7\% in Denmark.

In the 1960's, various publications about the changes in religious behaviour in Europe suggested the secularisation process as the main cause, and predicted a further deterioration of institutionalised religions. The process, as was expected, would gradually affect other continents and cultures since, by all means they would absorb the European Modernity and Enlightenment ideals.

Today, the data is interpreted in a different way, particularly as regards the secularisation hypothesis, although the geo-political substructure still remains. According to the main thesis, Europe is "the exceptional case" ${ }^{\text {" }}$. In the first place, in general, secularisation occurred in Western Europe. Peter Berger calls it 'Eurosecularity'. But that process has not been repeated in other continents. In her book, G. Davie discusses the distinct structural patterns and the evolution of religious behaviour in the different continents. And in the second place, the observed secularisation reflects a different reality than what was imagined some forty years ago ${ }^{47}$. Contrary to what he initially believed, P. Berger now asserts that religious pluralism does not necessarily lead to secularisation. "What pluralism does $(\ldots)$ is to undermine all taken-for-granted certainties, in religion as in all other spheres of life. But it is possible to hold beliefs and to live by them even if

${ }^{45}$ L. Halman, The European Values Study: a third wave: source book of the 1999/2000 European Values Study Survey, Tilburg 2001, Tilburg University Faculty of Social and Behavioural Sciences.

${ }^{46}$ G. Davie, Europe: The Exceptional Case. Parameters of Faith in the Modern World, London, Darton 2002, Longman and Todd.

${ }^{47}$ P. Berger, Postscript, in: L. Woodhead (ed.), Peter Berger and the Study of Religion, London 2001, Routledge, p. 194. 
they no longer hold the status of taken-for-granted verities"48. The main question then is to find out what people in the European context are doing with religion, be they Catholic, Protestant, Jewish, or Moslem, etc. tradition? And, apart from the French story discussed in a previous paragraph, what social position do the political institutions and the populations at large give to religion in their private life, and in the public sphere, in the different European countries? As a result, how does it affect their self-perception and their mutual relationships? The study of the religious behaviour in Limerzel (a Catholic parish in Brittany, France), at the beginning of the twentieth century and at the end of the second millennium offers an eloquent illustration of the drastic changes which occurred and highlights a coexistence of continuity and discontinuity and of the interrelatedness of the public and the private sphere ${ }^{49}$.

G. Davie is well known for her distinction of two typical characteristics of European religiosity. People vary in their way of maintaining the link between 'belonging' and 'believing', or the institutional, ritualistic, orthodox aspect on the one hand, and the subjective, experienced, personal response, on the other hand ${ }^{50}$. 'Belonging without believing' (which Davie associates with 'vicarious religion') refers to a high percentage of religious conformity and institutional attachment, and to a low level of personal involvement or faith (e.g. Britain, Sweden). 'Believing without belonging' refers to a high concern with feelings and personal experiences among the believers, and to a low percentage of religious practice (e.g. France). The two situations cannot be evaluated in the same way, since the former group especially displays "an undeniable degree of secularisation throughout Western Europe", while the latter group demonstrates considerable persistence $^{51}$. The figures do not suggest an overall attitude of non-belief or indifference. Historical, as well as geo-political circumstances, and a diversified 'logic' of being a religious person explain this very particular situation. The perception of the value of a growing diversity of religious belonging is also shifting. The opinion that all religions have their value is becoming a wide spread option among the young generation. It represents the symptom of a mutation of contemporary religious attitudes. In 1994, 16\% of the French sample declared: there is no 'one true religion'. In 1998, only 4\% in France, Britain and Germany

\footnotetext{
${ }^{48}$ Ibid., p. 194.

${ }^{49}$ Y. Lambert, From Parish to Transcendent Humanism in France, in: J. A. Beckford - Th. Luckmann (eds),

The Changing Face of Religion, op. cit., p. 49-63.

${ }^{50}$ G. Davie, Religion in Britain since 1945. Believing without Belonging, Oxford 1994, Blackwell; G. Davie, Europe: The Exceptional case, op. cit., p. $5 \mathrm{ff}$.

${ }^{51}$ G. Davie, Europe: The Exceptional Case, op. cit., p. 6-7.
} 
agreed with 'the truth is in one religion'. What does the difference between the (statistical) patterns represent? A more careful observation, based upon the results of surveys, suggests changes in religious sensitivity, does not necessarily coincide with what is induced by 'religious indifference'. Sociologists agree: churches in Europe continue to play an important role in society, despite the fact that less people practice their religion or profess the official creeds. Issues related to religious freedom, to the differences and contrasts between Central, Eastern, and Western Europe ${ }^{52}$, or aspects of the cultural and religious majority-minority balance are other dimensions of the specifically European religious situation.

The plurality of Europe not only implies different religions: Catholics, Protestants, Orthodox Christians, Jews, Moslems, but also different life visions, like Greek philosophy, the Roman law, the Renaissance, the Reformation, the Enlightenment, the French Revolution (separation of Church and State), the scientific mindset, different forms of humanism, etc. It is this complex network of influences that constitutes the symbolic field of the search for truth.

People hope to reach that kind of truth, which makes a difference for their lives. The hope for truth is still based upon the multiple influences of a long-standing and complex European history. While these different influences are not necessarily antagonistic, they may well cooperate in a collective and purifying process of discernment. Inevitably, eclecticism does occur, with the related uncertainty as regards to personal identity. Traditional religions are no longer contained within the usual territorial institutional boundaries, structures, functions, and disciplines. While individual people are caught between individualisation and mondialisation, the intermediate structures for controlling religions and life visions are disturbed. One can understand Cardinal Poupard's diagnosis and concerns when looking back at the comfortable monopoly of the Catholic Church. Other investigations don't sound as pessimistic, pointing out that the denominational cultures (Catholicism, Protestantism, etc.) are more resistant than expected, in supporting collective identities. ${ }^{53}$ Many of the aspects of the present situation can easily be misread and misinterpreted, when isolated from the complexity of the context.

J.-P. Willaime underscores a remarkable move from the historical "monopoly of Christian religion" in Europe to the - juxtaposed - co-existence of Catholics, Protestants, Jews, Moslems, and secular life visions, and then to a new 'homogeneity of the religious sentiment'. For him, six characteristics can be

52 D. Pollack, Religiousness Inside and Outside the Church in Selected Post-Communist Countries of Central and Eastern Europe, "Social Compass" 50 (2003), p. 321-334.

${ }^{53} \mathrm{~J}$. Astley, What Is Religion and Whose Faith Is It Anyway? Some Issues concerning the Nature and Normativity of Religion, and the Risks of Religious Education, in: H. Lombaerts, D. Pollefeyt (eds.), Hermeneutics and Religious Education, op. cit., p. 399-416. 
distinguished, which seem to be underlying the religious attitudes in Western Europe today ${ }^{54}$ : (1) individualisation (do it yourself; compose your own religious identity); (2) subjectivisation (the importance of personal religious experiences); (3) aestheticisation (a feel for staging the religious event); (4) emotionalisation (religion of the heart, opposed to the formal institutional religion); (5) ethicisation (focus upon human rights and ecumenism); (6) 'indifferentism' (relative meaning of the different doctrinal traditions; pragmatic participation).

\section{Rationality Perspective}

The third component of the systemic context of interreligious learning that I would like to explore deals with the emerging impact of rationality in Western Europe, closely related to modernity, the Enlightenment, and the scientific mindset. As a result of the democratisation of education, three trends in the social environment seem to affect the established religious consciousness and culture of Western Europe. The compulsory school career for all young generations desacralises the school; teachers and youngsters learn what 'schooling' is about in the first place. The alertness proper to a critical approach to life, and the sceptical attitude as regards the usual 'colonisation' of the mind cultivate a pragmatic attitude preventing students from being influenced by doctrinal or speculative orientations.

True, the laïcité-debate today seems to have found its reasonableness. The State does not want to deny any longer the original, specific value of religious, philosophical or wisdom traditions for public life. Rather than highlighting a conflict or competition of religious ambitions with the interests of the State, the main question now is to clarify the rational status of the fact that religious traditions do exist and continue to have influence upon people and upon society at large, including the political field ${ }^{55}$. What is the 'rational' way of dealing with the 'irrational' dimension of life, and in what terms is modern society going

\footnotetext{
${ }^{54}$ J.-P. Willaime, Europe et religions, op. cit., p. 67.

${ }^{55}$ In France, politicians, sociologists and philosophers alike use the expression "le phénomène religieux" or "le fait religieux" to identify a field of public interest, independently of a possible personal involvement. For more information, documentation, and bibliography, cf. www.enseignementet-religions.org. (11.03.2011). Cf. also R. Debray, Rapport de mission - l'enseignement du fait religieux dans l'école laïque, février 2002 (http://www.education.gouv.fr/rapport/debray/default. $\mathrm{htm}$ ), and a critical reaction by J. Joncheray, Enseignement du fait religieux dans l'Ecole laïque (http://www.catho-theo.net/article.php3?id_article=23) (09.03.2011).
} 
to support and manage its institutionalisation? ${ }^{56}$ This component, I think has a decisive importance for introducing IRL into religious education.

Post-modern rationality of coursediffers from what is traditionally called 'natural theology', which tried to prove rationally the existence of (the Judeo-Christian) God. Natural theology had strong universalist pretensions, and throughout history used a great deal of violence and destructive policies for imposing its dogmatic system upon other cultures, religious traditions, or alternative interpretations. This kind of theology tended to overlook the unconscious, and not intentionally sought after logic behind the non-rational aspects of the non Judeo-Christian belief systems. But, the so-called primitive religious systems obviously have their own cognitive content and rational impact upon the social reality. Anthropology, ethnology, and philosophy contribute to altering the overall perspective of looking at the religious phenomenon in whatever cultural or historical context, distancing their approach from a (natural) theological intelligence. As regards to the philosophical approach, Minguelez recalls three alternative ways of dealing with the 'rationality' problem ${ }^{57}$.

Philosophical empiricism claims that neither do religious beliefs have a factual content nor are there any purely rational proofs for Gods existence. The empirical sciences provide the appropriate approach to study the persistence of religious traditions, despite a process of modernisation and secularisation.

Post-modern fideism sees the religious field as a pluralist game of languages (Wittgenstein), rather than as a rational or irrational phenomenon. Religion refers to the function of religious beliefs in the life of the believers, and cannot be evaluated from an external viewpoint. It has its own coherent wisdom about life, where 'rationality' has no real competence.

Calvinis reformed epistemology, on the other hand can be compared to the meaning attributed to the 'individual' in the neo-liberal society. Subjectivism, undetermined rationality, individualism, and vagueness suggest that every model of rationality is doomed to fail.

The problems related to rationality and religion are obvious: what kind of rationality offers a solid and reliable base for a philosophy of religious behaviour? Is there only one kind of rationality, and what are its forms and models? If a variety of forms of rationality have been used over time, what were the respective consequences for culture and society? ${ }^{58}$ We should not forget that, in the Western

\footnotetext{
${ }^{56}$ R. Minguelez, La philosophie des religions et la sociologie des religions, «Social Compass» 49 (2002), p. 153-165.

${ }^{57}$ Ibid., p. 157-161.

${ }^{58}$ Ibid., p. 162.
} 
world (particularly Calvinist) Christianity contributed to the development of the capitalist system, and thus struggle for hegemony, for which the universal has a powerful strategic importance. Philosophers like Weber, Wittgenstein, and Habermas underscore the importance of a plurality of types of rationality. To recognise its relativity in critiquing the universalist pretension of the sciences of nature and the instrumentalist technological application of sciences would safeguard the real idea of rationality.

From a systemic point of view, Peter Beyer draws attention to the 'official' meanings attributed to religion, besides its scientific (i.e. the Academy) and theological conceptions. His argument precisely deals with the social stand religions make in modern society. It is the basic social-systemic structure of modern and global society, which leads him to this typology, because "each approach has its characteristic logic(s) grounded in the institutional priorities of the respective social systems that typically generate them" 59 . According to him, there is 'religiousness' outside religion, i.e., not included within the boundaries of socially formed religions ${ }^{60}$. Besides scholars and theologians, he sees the need for others elaborating more arbitrary - conceptions of religion: 'ordinary people', institutional representatives, and official centres of power (e.g., legal, political, educational, and mass-media systems). In modern society, a differentiated system for religion has developed and operates selectively. Beyer illustrates clearly in what sense different systems attribute different conceptions to religion, and thus grant religions a different social position a different status in society ${ }^{61}$. "How we conceive of religion depends on the social context or purpose we have for doing this". The Academy as well as theologians would contest this point of view, and claim a more general, universalist conception of religion, which for Beyer may not be of much use. It is also more important to recognise that others deal with religion and have influence upon the scientific and theological discourse.

In the same line of thought, for Thomas Luckmann, in Western Europe, religion underwent an epoch-making change of its social forms. Particularly, the modern, privatised, social form of religion is "the absence of plausible and generally obligatory social models for the persisting universal human experience of transcendence and the search for a meaningful life" ${ }^{\prime 2}$.

${ }^{59}$ P. Beyer, Conceptions of Religion. On Distinguishing Scientific, Theological, and "Official" Meanings, "Social Compass" 50 (2003), p. 142-143.

${ }^{60}$ Ibid., p. 153.

${ }^{61}$ Ibid., p. 156.

${ }^{62}$ Th. Luckmann, Transformations of Religion and Morality in Modern Europe, "Social Compass" 50 (2003), p. 282-283. 
In the actual discussion, 'invisible religion' ${ }^{63}$ is taken up again to understand the most recent developments. Moving beyond the hypotheses of secularisation (i.e. the loss of authority of religious institutions), Luckmann suggests identifying the more complex processes of "institutional deregulation" act of believing. However, according to Luckmann, "religion is not a passing phase in the evolution of mankind but a universal aspect of the conditio humana. Appearing under different socio-structural conditions in various historical forms, it remains a constituent element of human life, bonding the individual human being, most particularly its experiences of transcendence, to a collective view of the good life" ${ }^{65}$. However, the growing privatisation of religion redefined the general framework within which the churches were to coexist with other traditions and forms of religious experience. The demonopolisation of the production and distribution of world-views results in a variety of (new) suppliers on the market of world-views. Somehow, the churches are competing with other contemporary constructions of the sacred cosmos. The new social forms of religion and morality were superimposed upon a mixture of older ones. At the same time, the contents of religion and morality have changed significantly ${ }^{66}$, which makes it difficult to interpret the results of empirical investigation ${ }^{67}$. The shift from the great to the intermediate and minor transcendences contributes to the development of a nebula of small faith stories, more and more disconnected from the big stories administered by the traditional institutionalised religions ${ }^{68}$.

Over time, perceptions and interpretations of what is happening to the religious phenomenon in Western Europe are changing. As already mentioned, P. Berger is known for his idea of secularisation as a process of social disintegration of religious institutions $(1967)^{69}$. Understood in this sense however, secularisation,

${ }^{63}$ Th. Luckmann, The Invisible Religion. The Problem of Religion in Modern Society, New York 1967, Macmillan.

${ }^{64}$ D. Hervieux-Léger, Une sociologie des “modernités religieuses multiples”, «Social Compass» 50 (2003), p. 288.

${ }^{65}$ Th. Luckmann, Transformations of Religion and Morality in Modern Europe, op. cit., p. 276, italics in original text.

${ }^{66}$ Ibid., p. 283.

${ }^{67} \mathrm{P}$. Bréchon, L'héritage chrétien de l'Europe occidentale qu'en ont fait les nouvelles generations?, «Social Compass» 51 (2004), p. 216.

${ }^{68}$ D. Hervieux-Léger, Une sociologie des “modernités religieuses multiples”, op. cit., p. 288.

${ }^{69}$ P. Berger, The Sacred Canopy: Elements of a Sociological Theory of Religion, New York, 1967, Double Day. 
as an expulsion of religion, achieved its realisation only within Western Europe and Canada, and only in a particular sense ${ }^{70}$.

Following Berger, Hervieu-Léger also argues in favour of reconsidering the secularisation hypothesis ${ }^{71}$. Although the empirical observation of an 'objective secularisation', the loss of official religious beliefs and practices, of a feeling of being religious, is a matter of fact, the 'subjective secularisation', the depth attitudes of the individual people and of society, maintains strong ties with the original religious background. Secularisation then should include and integrate the diversity of configurations of religious modernity as they emerged in the different European contexts, and should not be associated any more exclusively with the idea of the loss or expulsion of religion. The concept of a (Catholic or Protestant) 'invisible religion' seems to be adequate for distinguishing paradoxical processes in the European context. Despite the loss of official beliefs and religious practices (i.e. objective secularisation) the depth structure of the initial religious socialisation remains very strong and still is a tool for encrypting the culture with Catholic, Protestant, or Jewish traditions. The symbolic structures of these traditions still have a remarkable impact upon culture and the environment, but much less in the traditional institutional social forms. Or, as Luckmann puts it: Religion and morality are still alive. Religion is not a passing historical phenomenon ${ }^{72}$. Depending upon how one looks at 'secularisation', one sees a loss, a radical break, or continuity. In turning their back to the institutional forms and norms for religious belonging, many people still keep their inbuilt Catholic or Protestant eye for perceiving the reality and for organising their interactions with the wider society. Catholics and Protestants more often have a similar relationship with society and respond more to traditional values than non-religious people.

The reinterpretation seems to be valid for the older generations. What do the young generations do with the Christian heritage in Western Europe ${ }^{73}$ The issue of a European Christian heritage proved to be of great interest (among church authorities and political leaders) at the occasion of the redaction of a European Constitution, but is it a symptom of strong identification within the Christian population at large?

${ }^{70}$ P. Berger (ed.), The Desecularization of the World: Resurgent Religion and World Politics, Grand Rapids 1999, MI, Eerdmans.

${ }^{71}$ D. Hervieu-Léger, Une sociologie des “modernités religieuses multiples", op. cit., p. 289293; see also D. Hervieu-Léger, The Twofold Limit of the Notion of Secularisation, op. cit., p. 112-125.

${ }^{72}$ Th. Luckmann, Transformations of Religion and Morality in Modern Europe, op. cit., p. 183-184.

${ }^{73}$ P. Bréchon, L'héritage chrétien de l'Europe, op. cit., p. 204-206. 
According to Bréchon, the so-called "Christian heritage" is becoming something different. The younger generations do not go back to a Christianity of the past. What they do with religion is rather a recomposition than a return, and reflects a complex reality. Particularly young people, more than the older generations, recompose their religiousframes of reference and religious behaviour in sometimes very loose forms, with paradoxical, non-justified or undocumented statements, outside the big religious stories and institutional dogmas. Only a minority of young people tend to develop a defined religious identity, with strong consequences for their life attitudes ${ }^{74}$.

As Beyer states, the (changing) social systems generate institutional priorities. A century ago, religious people's lives were organised according to rituals and the fixed, stable rhythm of liturgical seasons. For people today, the religious or other transcendental support does not have the same importance. Modern people departed from the 'Aberglauben', the 'fairy tails', as Dietrich Bonhoeffer, Hans Jonas, Emmanuel Levinas, and others point out in relationship to the devastating impact of the Holocaust. The general assumption now states that we are personally responsible for our life options and for the consequences, and not the 'gods'. In modern consumer society, individualism, fashion, the media, and virtual communication highlight the extroverted personality. The 'rationality' behind it disturbs the traditional religious institutional order, rooted in interiority, in a modest, inward-looking, and ritualised self-control in view of a transcendent world. But the religious quest remains, albeit in different ways, and often looked for outside the official boundaries of the traditional religions.

Who then is taking the lead? The "rationalities" generated by contemporary society infiltrate into schools and class groups. It is an important matter for teachers to recognise the explicit or implicit reasoning behind slogans, life styles, communication styles, artefacts, de-constructive responses to what teachers or witnesses of the institutional order represent. Plurality and diversity of sensitivities, perceptions, understanding, of handling data and insights create a new learning situation, the rationality of which is totally alien to the 'transmission' teaching model aiming at reproduction and uniformity. Teachers of religion are now expected to be 'hermeneutists', and experts in communication ${ }^{75}$.

Obviously, Beyer's, Luckmann's, and Hervieu-Léger's observations have important implications for interreligious dialogue and learning.

${ }^{74}$ Ibid., p. 216.

${ }^{75}$ H. Lombaerts, De klas als leergroep. De leerkracht als hermeneut, in: H. Lombaerts, B. Roebben (eds.), Godsdienst op school in de branding. Een tussentijdse balans, Deurne 2000, Wolters Plantijn, p. 67-80; H. Lombaerts, Godsdienstonderricht als communicatieve gebeurtenis, in: Ibid., p. 81-107. 


\section{Theological Debates and Interreligious Dialogue}

Both the European Enlightenment and the so-called critique of religion (Religonskritik) had a deep impact upon the social position of religion in society. They also stimulated the emergence of a variety of forms of emancipation for the modern person, and initiated new forms of communication and encounters ${ }^{76}$. According to J. Waardenburg, one can distinguish different degrees of 'condensation' of religiousness within the traditional churches or in separate religious groups and movements. Some types of religious orientations easily share interests, forms of commitment, and solidarity with other religious or secular groups, e.g. in supporting an 'ecumenism of human rights', or in using secular, scientific methods for investigation and analysis. Other religious groups or institutions are not against integrating themselves into a pluralist environment, but continue to follow a well-defined proper life. Still other groups and people want to defend the full and separate autonomy of religious traditions, despite the secular environment. And finally, some religious groups focus upon an exclusive, puritanical orthodoxy, often in opposition to the secular environment.

These and similar affinities, and the related theological debates have their implications for interreligious dialogue, and consequently for interreligious learning. As G. De Schrijver points out, the tension between the 'inwardness' of religious groups and the commitment for social justice, for example is one of the core issues of recent confrontations among theologians and church leaders ${ }^{77}$. In John Milbank, as G. De Schrijver argues, "theology does not stand in need of any secular mediation (and social analysis is one of them) since it harbours within itself the basic principles that are needed to pass a judgment on all the rest, secular matters included". Hence Milbank's opposition to the secular discourse, to liberation theologies (using social analysis), and to interreligious dialogue, in the name of Christian uniqueness, as Christianity does not stand in need of any cross-fertilization by other religions (outside the church no salvation)"78. The Italian philosopher Gianni Vattimo, on the contrary, welcomed the secularisation movement of the second half of the twentieth century: "'Secularisation' is the authentic destiny of Christianity (and not it's abandonment and negation)" ${ }^{\text {"79. }}$. For

${ }^{76}$ J. Waardenburg, Religionskritik, Aufklärung, Emanzipiering, Begegnung, in: H. R. Schlette (ed.), Religionskritik in interkultureller und interreligiöser Sicht, op. cit., p. 196-208.

${ }^{77}$ G. De Schrijver, Recent Theological Debates in Europe. Their Impact on Interreligious Dialogue, Bangalore 2004, Dharmaram Publications, p. 15.

${ }^{78}$ Ibid., p. $101 \mathrm{ff}$; also, E. Poulat, Notre laïcité publique, op. cit., p. 29-30.

${ }^{79}$ G. De Schrijver, Recent Theological Debates in Europe (n. 80), p. 30, quoting G. Vattimo, Beyond Interpretation. The Meaning of Hermeneutics for Philosophy, Cambridge 1997, 
G. Vattimo, the recent rediscovery of one's temporality, finitude, and mortality has a religious character. The involvement with the changes affecting contemporary society, with the vicissitudes of life, and with the radical contingency of existence puts us in touch with the figure of the Son Incarnate. For G. Vattimo, God's kenosis in Christ constitutes the core of the turnover in the present religious orientation. The kenotic (God's self-abasement in Christ) approach to plurality, for example opens perspectives for perceiving non-Christian religions in a different light. The kenotic event sets us free to perceive the manifold manifestations of God and helps us to see the mystical core and the ideals of self-giving of other religions ${ }^{80}$. Following G. Vattimo's reading of the Christian tradition, De Schrijver is convinced that "a deeper understanding of one's own tradition of kenosis is indispensable for awakening a sensitivity to emptiness and 'letting go'. In this appreciation one can even go so far as to engage in a cross-fertilisation by nonChristian mysticism" $"$.

Equally for J.-B. Metz, the suffering people, especially those innocent who are suffering unjustly, have a unique moral authority ${ }^{82}$. For J.-B. Metz, it is the only authority in which Gods authority becomes manifest to all people and gives a universal dimension to the suffering in the world. To be 'obedient' to the suffering of innocent people precedes even understanding and discourse. To put the suffering of others at the core of today's reflection then constitutes a presupposition for every truth-claim, including that of religions. The official Godtalk should let go of the universal, strong, power-based monotheistic discourse. It raises suspicion among the contemporary educated generations. The biblical tradition, on the contrary reveals a weak, vulnerable, and empathic monotheistic God image the question about how to relate God and human suffering or evil is as its core. According to Metz, this paradigm can justly claim a universal meaning and value without the risk of being imperial or totalitarian.

In that sense, the direct contact with non-Western cultures and non-Christian religions creates the revelatory space where the kenotic 'return to religion' (cf.

\section{Polity Press, p. 51.}

${ }^{80}$ For J. Dupuis, "religions in themselves are as many 'gifts of God to all people", as distinguished from "what they too often become at the hands of human beings, being used as ideology justifying unworthy purposes". J. Depuis, "Christianity and the Religions" Revisited, "Louvain Studies" 28 (2003), p. 367.

${ }^{81}$ G. De Schrijver, Recent Theological Debates in Europe, op. cit., p. 33.

82 J.B. Metz, Im Eingedenken fremden Leids. Zu einer Basis- und Brückenkategorie der christlichen Gottesrede, in: H.R. Schlette, Religionskritik in interkultureller und interreligiöser Sicht, op. cit., p. 141-144. 
G. Vattimo) is rediscovered as a new hermeneutic key for making progress in the realm of interreligious learning.

But the explicit interest for interreligious dialogue in the Catholic Church only came into the picture - again - during the second half of the twentieth century. The first initiatives of dialogue gathered together mainly Western European Christians and representatives of non-Christian religions trained in the Western world. The integration of the Enlightenment and the critique of religion proved to be a complex process, which needed time to emerge within religious consciousness. Also, the Christian Europeans needed to overcome the exclusive 'missionary' attitude and deconstruct the multiple 'constructs' about non-Christian religions, for having access to different theological perceptions of what other religions stand for ${ }^{83}$.

According to J. Dupuis, only after Vatican II does the Catholic Church progressively rediscover that God's Spirit is present in the religious life of other religions and works through their traditions, as it does in the Christian Churches. Particularly Pope John Paul II developed the vision of the universal working of Gods Spirit in non-Christian religions and, in this sense offered a strong theological basis for interreligious dialogue, based upon the "mystery of unity" $"$. He organised unprecedented initiatives to implement his conviction in a worldwide perspective. The dialogue is, for John Paul II, of a theological and christological nature. Christians know, by faith, of the salvation in Christ, while the others remain unconscious of Christ as the source of their redemption.

It is only towards the end of the twentieth century, that the North-South problematic for example challenged the world religions to cooperate and to commit themselves in efforts for mutual understanding and for creating synergies not only in the area of social justice, but also at the explicitly religious level. In the $21^{\text {st }}$ century, it is obvious that world religions try to develop a more outspoken profile. In the public political debates, 'religion' in its diversity is recognised as a core dimension of the life of individuals and of societies as an essential factor of the identity of people and cultures. Religion is now granted a different and determining role in intercultural contacts, in the peace process, and in local or international conflicts, and in handling ethical dilemmas, although in certain countries, discrimination and persecution of Christians lead to critical situations. The more frequently people live open contacts with other religions, the more the officially recognised heterogeneity of religions will stimulate initiatives to

${ }^{83}$ J. Waardenburg, Religionskritik, op. cit., p. 205-207.

${ }^{84}$ J. Dupuis, Der Interreligiöse Dialog als Herousforderung für die christliche Identität, „Zietschrift für Missionswissenschaft und Religionswissenschaft“ 88 (2004), p. 9-10. 
enhance self-understanding and intra-religious dialogue. Multi-religious contacts will contribute to a more appropriate interpretation of characteristics of religions, to strengthen their inner coherence and to deal with the specific structures more appropriately. More explicit attention is given, also in the media to the images religions inherited or constructed. More accurate information often helps to deconstruct false images, and to overcome prejudices.

Apart from the discussion about the exclusive, inclusive, pluralist, or inclusive pluralist understanding of interreligious dialogue, the question of the personal faith involvement of the dialoguing partners, and of the religiosity of the interreligious dialogue itself, is a decisive aspect. According to James Heisig ${ }^{85}$, the "business of getting together is neither mere talk about religion, nor mere religious theory, but is itself a religious act" ${ }^{\$ 16}$. In order to prevent the interreligious dialogue from being pre-evangelisation, J. Heisig prioritises three criteria: 1/ the practice of the common sense core attitude of dialogue and self-criticism; $2 /$ to be sensitive to the esteem for people's submission to the authority of Tradition and for the tenacity of one's beliefs, religion being at the limits of reason; and 3/ to recognise that interreligious dialogue is about a mutual conversion; the evolution of one's own symbolic system is enriched and challenged by that of other faiths ${ }^{87}$.

This implies that the status given to religions in the interreligious dialogue is of crucial importance for its ultimate credibility. Where do the partners belong in the first place? For J. Heisig, "one's primary religious allegiance can be the point at which religious faiths together open out to responsibility for the world, and the secondary allegiance to that concrete set of symbols or revelations within which one lives and thinks" ${ }^{\prime \prime}$. The mutual conversion then is not about shifting to the other's religious paradise, or making a joint statement, but of "conversion through a dialogue to a kind of interreligiosity, a broadening of religious loyalties beyond one's particular affiliation and awakening to the need of mutual support for moral praxis" $"$. The practice of interreligious dialogue, which aims at a personal change of the partners involved is not a mere individual matter, but also affects the structure of religious institutions.

J. Dupuis insists upon both the inductive and deductive approaches to interreligious dialogue: to proceed from the basic experience of religious

\footnotetext{
${ }^{85}$ Nanzan Institute for Religion and Culture, Japan.

${ }^{86}$ J.W. Heisig, Dialogues At One Inch Above The Ground, New York 2003, Herder \& Herder, p. 128.

${ }^{87}$ Ibid., p. 129-133.

${ }^{88}$ Ibid., p. 131.

${ }^{89}$ Ibid., p. 133.
} 
plurality to the interpretation, in the light of this reality, of the data of revelation and tradition, or to proceed from the Christian tradition to the concrete reality of dialogue $^{90}$. J. Heisig articulates the dialectic interaction between one's personal particular faith tradition, and the changes (conversion) occurring in the space of interreligiosity.

According to J. Heisig, with a further articulation of what interreligiosity means from the perspective of our Christian tradition, we enter a fifth phase at the beginning of the third millennium. Two thousand years ago, there were the teachings of Jesus, with little organisation or uniformity. The second phase coincides with the transformation of the teachings of Christ into a systematisation of doctrines, practices, and structures, of changing leadership into a hierarchical church. In the third phase, Christianity became a mode of civilisation associated with the assumption of secular power, characterised by uniformity, orthodoxy and standardisation. In the fourth phase, the Christian religion is considered as one religion in a multireligious world, and is no longer the religion par excellence. In the fifth phase, the present time, when religious consciousness identifies itself as Christian, but without belonging to a particular ecclesiastical institution, we are confronted with the emergence of "Christianness" (Raimon Panikkar) ${ }^{91}$. Here, J. Heisig connects with the numerous sociological observations and with pastoral experience when observing "belonging to Christendom, whether in its conservative or reformist branches, is not an issue for the majority of Christian believers today". People no longer identify in the first place with the institutional church, which, as such, does not mean disinterest or indifference as regards to human and political matters or religious quests. He rather interprets it as "disestablished Christianity, or disestablished faith". Tradition and institutions maintain their importance, but only selectively, and the criteria for selection are viewed differently ${ }^{92}$. Alternative 'grass-roots' communities (in Africa and Asia) or liberation theology (in Latin America), for example, aim at saving the spirituality of human dignity, which J.-B. Metz, G. Vattimo, Ignacio Ellacuria ${ }^{93}$, and De Schrijver identify as the kenotic paradigm of religious commitments. The shift to 'Christianness' and 'disestablished Christianity' is partly responsible for theological and institutional misunderstandings and conflicts, which affect the potentiality and the limitations of interreligious learning. What then are the implications of these different social positions of religions in society for IRL?

\footnotetext{
${ }^{90}$ J. Dupuis, "Christianity and the Religions" Revisited, op. cit., p. 364-366.

${ }^{91}$ J. Heisig, Dialogues At One Inch Above The Ground, op. cit., p. 171.

${ }^{92}$ Ibid., p. 172.

${ }^{93}$ G. De Schrijver, Recent Theological Debates in Europe (n. 80), p. 263-338.
} 


\section{Implications for IRL}

What is to be learned in interreligious learning? The deepening of the beliefs and traditions of one's own particular religion; what other religions mean (R.E. curricula); what Christianness means (Panikkar); religious sensitivity (Willaime); interreligiosity (Heisig)? One can assume that for the first two options, the learner does not take too many risks. He or she can remain in the safe, protected territory of a clearly defined religious identity. The other religions can be explored as 'other', distinct from one's personal commitments. The other three options however are situated at the boundary, at the interface. They are dealing, in the first place with the 'film', which keeps the different religions separate, but which, at the same time, allows mutual exchange and interdependent interaction. However relevant, the material content of the different creeds, practices and traditions are of secondary importance. Traditions keep their importance, but only in a selective way (J. Heisig). The historical and geo-political layer hides a lot of the original value and meaning of the genius of each one of the religions, hinders mutual understanding, and prevents people from trusting their respective creative exploration of the mystery of life and God's mystery. Judith A. Berling explains how much the exclusivist attitude among Christians, in the U.S.A., made it very difficult to introduce the study of other religions into institutions of higher education despite the fact the different denominations and cultures were represented in the classroom ${ }^{94}$. It is that layer, which should be looked at, as it holds the hermeneutic key for entering into the others 'temple'. It also holds the key for understanding the respective ways of dealing with "the great moral challenges posed to us by the megalopolis, the globalisation of poverty, the dwindling protection of human rights, and the trashing of as much of the cosmos as our civilisation can get its hands on"95. To limit IRL to a mere materialisation of religions, to the 'realia', would sterilise the whole project of interreligious learning. For Berling, in order to avoid this kind of failure, 'learning religions' should move beyond 'science', beyond 'empathy', beyond the 'religious mind', and beyond 'intercultural stereotypes' ${ }^{96}$. J. Heisig argued in favour of mutual 'conversion', without proselytising interests, as the main goal for the partners involved in interreligious dialogue. Christianness "takes the Christian religion not only beyond the walls of ecclesiastical institutions, but beyond the frontiers of

${ }^{94}$ J.A. Berling, Understanding Other World Religions. A Guide for Interreligious Education, New York 2004, Orbis Books, p. 7-11.

${ }^{95}$ J. Heisig, Dialogues At One Inch Above The Ground, op. cit., p. 184.

${ }^{96}$ J.A. Berling, Understanding Other World Religions, op. cit., p. 34-48. 
the primacy of Christ. For the turn from Christianity as a religion to Christianness also opens the possibility of those in other religions converting to Christianity without forsaking their own primary symbols or even their institutional affiliation. Conversely, it opens the possibility of Christians inheriting the religious riches of other religions, such as Buddhism and Islam, not as mere ideas, but into their own religious consciousness and practice. In short, the transition to Christianness does not do away with the Christian mission but alters its nature from a confrontation between religions to a synthesis within personal religious consciousness" ${ }^{997}$.

For IRL to make sense, in view of interreligious dialogue, it should forsake its merely 'functional' goals (studying and comparing the respective doctrines, exploring and adjusting rituals and prayers, etc.). Rather, it needs to cultivate an overall climate of gratuity, of disinterest, and of practicing interreligious dialogue for its own sake as a religious act. In the final chapter of his book, 'What time is it for Christianity?' J. Heisig offers very powerful and insightful perspectives for introducing a new era as regards to the emergence of an interreligious universe in the $21^{\text {st }}$ century ${ }^{98}$. We need a broad and daring vision for a common inspiration, for establishing solid grounds, for welcoming new religions, for cooperation among the world religions, and for 'conversion'.

The interreligious dialogue finds its aim in itself: dialogue for its own sake among believers of different traditions. Religions themselves ask for mutual understanding of their respective search for religious truth. Not understanding the other would be the "normal" situation ${ }^{99}$. In daily life, people aim for a pragmatic mutual understanding; they have to live and act together they don't necessarily see any benefit in deepening the otherness or subjectivity of the other person.

Of course, the mutual settlement among different traditions in a particular environment already happened in the past according to the perception and understanding, or lack of understanding of the deepest core of the other religions. The confrontation with a changing social environment, and the need for further mutual adjustments bring to light the historical, and thus changing nature of the interreligious dialogue. Hence the major concern of a hermeneutics of interreligious communication: to recognise its complexity, to understand its processes, to become conscious of the risk of its failure. Philosophical hermeneutics aims for a deep understanding of the other's belief with the recognition of each other's freedom, the discovery of similarities and harmony. The confrontation with

\footnotetext{
${ }^{97}$ J. Heisig, Dialogues At One Inch Above The Ground, op. cit., p. 173.

${ }^{98}$ Ibid., p. 187-215.

${ }_{99}$ M. Bongardt (ed.), Vorwort, in: Verstehen an der Grenze. Beiträge zur Hermeneutik interkultureller und interreligiöser Kommunikation, Münster 2003, Aschendorf, p. 7ff.
} 
'otherness', however keeps putting the hope for full understanding into question. Can 'otherness' and strangeness be overcome? Is the hope for interreligious dialogue, then an unrealistic dream, an idealistic illusion? ${ }^{100}$.

Mutual rapprochement has its own limitations, and should avoid fusion or illusory unity. The interreligious dialogue requires a specific hermeneutic approach, based upon a deeper understanding of the personal faith tradition. The dialogue is happening at the boundary of different religious, imaginary, cultural identities and geo-political territories. The creation of the in-between zone guarantees (a limited) success of interreligious understanding. The understanding itself is limited ${ }^{101}$.

What we should pay attention to, then is the much vaster and deeper mutation or metamorphosis of the religious interest itself, we should also pay attention to the interaction of institutional religions with their social environment. Only internationally coordinated initiatives will have the potential to overcome intercultural and interreligious stereotypes. Edward W. Said is known for his study of orientalism. "Orientalism is a style of thought based upon ontological and epistemological distinction made between 'the Orient' and (most of the time) 'the Occident'. Thus a very large mass of writers, among who are poets, novelists, philosophers, political theorists, economists, and imperial administrators, have accepted the basic distinction between East and West as the starting point for elaborate accounts concerning the Orient, its people, customs, 'mind', destiny, and so on" ${ }^{102}$. Orientalism is the generic term "to describe the Western approach to the Orient, the discipline by which the Orient was (and is) approached systematically as a topic of learning, discovery, and practice, the collection of dreams, images, and vocabulary available to anyone who has tried to talk about what lies east of the dividing line"103. But, similarly, occidentalism expresses comparable stereotypes as regards to the Western world. The West is inhuman. Modernity, the Enlightenment, colonialism, imperialist Americanism... are all diabolic aspects of a world, which is to be loathed and hated. One should not identify these two stereotypes with territorial boundaries, though. The two attitudes can occur anywhere in the world ${ }^{104}$.

\footnotetext{
${ }^{100}$ J.A. Berling, Understanding Other World Religions, op. cit., p. 15-17.

${ }^{101}$ M. Bongardt, Verstehen an der Grenze, op. cit., p. 16.

${ }^{102}$ E.W. Said, Orientalism: A Brief Definition, http://www.postcolonialweb.org/uk/ishiguro/orientlm.html (11.03.2011).

${ }^{103}$ E.W. Said, Orientalism, London, Penguin Books, 1995, p. 73; Cf. also J. Berling, Understanding Other World Religions, op. cit., p. 43.

${ }^{104}$ I. Buruma, A. Margalit, Occidentalisme. Het Westen in de ogen van zijn vijanden, trans.
} A. Klootwijk, Antwerp, Atlas 2004, p. 7-17. 
Analogously, and historically speaking, what is called 'indifference' - in the sense of not showing interest because what is offered does not make a difference (anymore) - emerges from Christianity itself, when affected by the Enlightenment and modernity, by the demographic changes and the neo-liberal orientation of contemporary society. The churches are struggling today with problems, which cannot be identified simply as atheism, irreligion, non-belief, denial of the social, ethical role of religion, denial of the authority of the churches, denial of the prophetic role of religions, disappearance of religions, of church buildings, or mere religious passivity, or apathy. As some will point out, indifference should not be observed among the 'unfaithful' Christians alone. The churches are accused of being indifferent towards the new sensitivities of people today. Diversity or plurality became one of the core conditions of today's society. Educational theorists explored some of the critical aspects of learning in a diverse world. And this could be crucial for interreligious learning ${ }^{105}$.

Confronted with the religious plurality among pupils in schools, religious educationalists see "inter-religious learning" as a new paradigm for religious learning. In case IRL is aiming at interreligious dialogue and communication, the basic understanding of such a communication is to be kept in mind. Conversation, reminds M. Wörner relies upon an interfering communality among the communicators, according to which the partners accept to be guided freely, unconstrained and closely connected, by the theme and by the communication process $^{106}$.

The traditional paradigm of mono-religious education assumes the furthered initiation in one particular religious tradition and the deepening of a respective religious identity. The institutional context of denominational schools - as it is the case for many youngsters in christianised Europe - and the compulsory status of the religion class are intended to reinforce not only the 'believing', but also the 'belonging'. The purpose being that children and youngsters remain faithful to the tradition of their initial socialisation and own it personally and in this way guarantee the continuity of the church. This expectation is coherent with the aims and aspirations of a religious tradition. The concept is severely challenged, however by the plurality of the religious attitudes and beliefs of the faithful, as the sociological inquiries point out. This situation is reflected in the classroom, among

${ }^{105}$ J. Berling, Understanding Other World Religions, op. cit., p. 17-33, esp. 33.

${ }^{106}$ M. H. Wörner, Interreligiöse Verstandigung als Gespräch? Vorüberlegungen zur Hermeneutik interreligiöser Kommunikation, in: M. Bongardt (ed.), Verstehen an der Grenze, op. cit., p. 39. 
teachers and students ${ }^{107}$. Teachers have different concepts of teaching religion and working with their students. A systematic investigation reveals a typology of four different logics of handling the teaching and learning of religion. Some work according to a 'committed Christian model', others are more at home with a 'tolerant model', a third category reflects a pessimistic 'discontinuity' model, and a fourth group of teachers aim for an open and constructive 'cooperation' with their students ${ }^{108}$. But also the students seem to reflect a similar diversity as regards to their religious attitudes and dealings with religious education in schools. Some can be associated with an 'open pluralistic model' of attending religion classes, others reflect a 'closed Christian model', a third category refers to 'experiences in their family' for expressing their affinities with religious education, a fourth group goes along with a 'cooperation model', and a fifth group identifies with 'discontinuity' ${ }^{109}$. In both cases, the teachers identified as 'tolerant' and students of the 'open pluralistic model' seem to be the closest to openness towards interreligious learning.

When taking the institutional context into consideration, some questions are to be raised. Is IRL compatible with the agreement between Church and State as regards to RE in schools? What is the weight of the sociological observation of religious plurality among youngsters in relationship to the right, obligation, or mission religious authorities grant themselves for teaching religion in schools? Where would IRL belong in the existing institutional (denominational) setting? What kind of theological paradigm will receive a convincing consensus for supporting IRL? Who eventually has the legal authority to develop its specific model to set the rules for its pragmatic implementation in the classrooms and to act as an IRL teacher?

${ }^{107}$ D. Pollefeyt, D. Hutsebaut, H. Lombaerts, M. De Vlieger, A. Dillen, J. Maex, W. Smit, Godsdienstonderwijs uitgedaagd. Jongeren en (inter)levensbeschouwelijke vorming in gezin en onderwijs, Leuven 2004, Peeters.

${ }^{108}$ Ibid., p. 208-215.

${ }^{109}$ Ibid., p. 537-543. 


\section{Bibliography}

Berling J.A., Understanding Other World Religions. A Guide for Interreligious Education, New York 2004, Orbis Books.

Bongardt M. (ed.), Verstehen an der Grenze. Beiträge zur Hermeneutik interkultureller und interreligiöser Kommunikation, Münster 2003, Aschendorf.

Davie G., Europe: The Exceptional Case. Parameters of Faith in the Modern World, London, Darton 2002, Longman and Todd.

De Schrijver G., Recent Theological Debates in Europe. Their Impact on Interreligious Dialogue, Bangalore 2004, Dharmaram Publications.

Halman L., The European Values Study: a third wave: source book of the 1999/2000 European Values Study Survey, Tilburg 2001, Tilburg University.

Heisig J.W., Dialogues At One Inch Above The Ground, New York 2003, Herder \& Herder.

J.-P.Willaime, J.-R. Armogathe (eds.), Les mutations contemporaines du religieux, Turnhout 2003, Brepols.

Lombaerts H., Pollefeyt D. (eds.), Hermeneutics and Religious Education, Leuven 2004, Peeters.

Lombaerts H., The Impact of the Status of Religion in Contemporary Society Upon Interreligious Learning, in: D. Pollefeyt (ed.), Interreligious Learning, Leuven, 2007, Peeters, pp. 55-86.

Smart N., Atlas of the World's Religions, Oxford 1999, Oxford University Press.

Taylor C., Appiah K.A., Habermas J., Gutmann A., Multiculturalis. Examining the Politics of Recognition, Princeton 1994, Princeton University Press.

Willaime J.-P., Europe et religions. Les enjeux du XXIe siècle, Paris 2004, Fayard. 